\title{
ŹRÓDŁA FINANSOWANIA OCHRONY ZDROWIA W WYBRANYCH PAŃSTWACH EUROPEJSKICH - ANALIZA PORÓWNAWCZA
}

\author{
Rafał Zachorowski ${ }^{1}$ \\ Uniwersytet Ekonomiczny w Katowicach \\ Kolegium Finansów
}

\begin{abstract}
Streszczenie: Najpowszechniejszym źródłem finansowania wydatków związanych z funkcjonowaniem opieki zdrowotnej w Europie są obowiązkowe ubezpieczenia zdrowotne. Łącznie pokrywają one $40,11 \%$ ogółu wydatków. Na drugim miejscu znajduje się finansowanie budżetowe stanowiące $37,64 \%$ ogółu wydatków. Inne źródła finansowania mają charakter pomocniczy w powszechnym systemie ochrony zdrowia. Z przeprowadzonej analizy wynika, że obecnie rozwinięte państwa w znacznej większości preferują systemy opieki zdrowotnej w przeważającej mierze finansowane ze środków publicznych. Sam system opieki zdrowotnej podlega zaś daleko idącej kontroli i zarządzaniu przez instytucje państwa.
\end{abstract}

Słowa kluczowe: finansowanie ochrony zdrowia, ochrona zdrowia, struktura źródeł finansowania ochrony zdrowia

DOI: $10.17512 /$ znpcz.2020.3.08

\section{Wprowadzenie}

Zakres odpowiedzialności państwa za ochronę zdrowia oraz jej formy są różne w poszczególnych krajach Europy. Różnice wynikają w większym stopniu z procesu historycznego niż świadomych decyzji różnicujących poszczególne modele zarządzania ochroną zdrowia. Należy podkreślić, że ogólny poziom możliwości finansowych państwa decyduje o proporcjach pomiędzy poszczególnymi źródłami finansowania.

\section{Formy finansowania wydatków zdrowotnych w Europie}

System raportowania Narodowych Rachunków Zdrowia przewiduje określone formy finansowania wydatków zdrowotnych w poszczególnych państwach. Podstawowe formy finansowania to:

- finansowanie ze środków budżetowych;

- obowiązkowe ubezpieczenia zdrowotne;

- dobrowolne ubezpieczenia zdrowotne, niezależnie od ich subsydiowania przez budżet państwa;

- finansowanie przez instytucje społeczne nie kontrolowane przez państwo, dostarczające swoje usługi nieodpłatnie bądź po cenach niższych od rynkowych;

\footnotetext{
${ }^{1}$ Rafał Zachorowski, dr, zachorowskir@wp.pl
} 
- zabezpieczenie zdrowotne o charakterze nieubezpieczeniowym zapewniane przez przedsiębiorstwa dla własnych pracowników;

- bezpośrednie finansowanie opieki zdrowotnej przez pacjentów;

- finansowanie ze źródeł zagranicznych.

Finansowanie ze środków budżetowych oznacza, że pewne rodzaje kosztów związane $\mathrm{z}$ funkcjonowaniem ochrony zdrowia pokrywane są bezpośrednio ze źródeł rządowych, a rząd lub jego agencje odpowiadają za realizowane zadania.

W ramach obowiązkowych ubezpieczeń zdrowotnych środki na funkcjonowanie ochrony zdrowia zapewniane są poprzez przymusowe ubezpieczenia całych grup społecznych. Uprawnienia do korzystania z opieki zdrowotnej wynikają z uczestnictwa $\mathrm{w}$ powszechnych systemach ubezpieczeń zdrowotnych. Istotne znaczenie w finansowaniu opieki zdrowotnej posiadają fundusze unijne (Skowron-Grabowska, Jasińska, s. 7).

Z danych Eurostatu za rok 2015 wynika, że najpowszechniejszym źródłem finansowania wydatków związanych $\mathrm{z}$ funkcjonowaniem opieki zdrowotnej w Europie są obowiązkowe ubezpieczenia zdrowotne. Łącznie pokrywają one 633 mld euro wydatków sektora, co stanowi 40,11\% ogółu wydatków. Na drugim miejscu znajdują się wydatki budżetowe o wartości 594 mld euro (37,64\%). Obydwa źródła finansowania stanowią podstawę większości systemów opieki zdrowotnej funkcjonujących w Europie. Inne źródła finansowania mają charakter pomocniczy w państwowym systemie ochrony zdrowia lub wynikają z potrzeb ludności nie zaspokajanych w systemach powszechnych. Tym należy tłumaczyć wysoki odsetek finansowania świadczeń zdrowotnych bezpośrednio ze źródeł gospodarstw domowych w wysokości 258 mld euro, co stanowi ponad $16,34 \%$ ponoszonych wydatków. Inne formy finansowania są znacznie mniejsze i pokrywają jedynie niecałe $6 \%$ kosztów.

Tabela 1. Udzial poszczególnych źródel finansowania w sektorze ochrony zdrowia w Europie w 2015 roku

\begin{tabular}{|c|c|c|}
\hline Forma finansowania & Wartość w mln euro & $\begin{array}{c}\text { Udział } \\
\text { procentowy }\end{array}$ \\
\hline Finansowanie budżetowe & 593986,90 & $37,64 \%$ \\
\hline Obowiązkowe ubezpieczenia zdrowotne & 633091,39 & $40,11 \%$ \\
\hline Dobrowolne ubezpieczenia zdrowotne & 74059,72 & $4,69 \%$ \\
\hline $\begin{array}{c}\text { Finansowanie ze źródeł organizacji } \\
\text { społecznych }\end{array}$ & 10712,90 & $0,68 \%$ \\
\hline $\begin{array}{c}\text { Pracownicze formy zabezpieczenia } \\
\text { zdrowotnego }\end{array}$ & 8175,93 & $0,52 \%$ \\
\hline $\begin{array}{c}\text { Bezpośrednie płatności pacjentów } \\
\text { na rzecz świadczeniodawców }\end{array}$ & 257939,85 & $16,34 \%$ \\
\hline $\begin{array}{c}\text { Finansowanie ze źródeł zagranicznych } \\
\text { RAZEM }\end{array}$ & 282,43 & $0,02 \%$ \\
\hline
\end{tabular}

Źródło: Opracowanie własne na podstawie danych Organizacji Współpracy Gospodarczej i Rozwoju (https://stats.oecd.org/) 
Tabela 2. Procentowy udział poszczególnych źródeł finansowania wydatków ponoszonych w ramach systemu ochrony zdrowia w wybranych państwach europejskich w 2015 roku

\begin{tabular}{|c|c|c|c|c|c|}
\hline Wyszczególnienie & Bułgaria & Czechy & Niemcy & Francja & Polska \\
\hline Finansowanie budżetowe & $9,20 \%$ & $12,17 \%$ & $6,70 \%$ & $5,10 \%$ & $9,25 \%$ \\
\hline $\begin{array}{c}\text { Obowiązkowe } \\
\text { ubezpieczenia zdrowotne }\end{array}$ & $41,89 \%$ & $71,28 \%$ & $77,60 \%$ & $71,48 \%$ & $60,74 \%$ \\
\hline $\begin{array}{c}\text { Dobrowolne ubezpieczenia } \\
\text { zdrowotne }\end{array}$ & $0,40 \%$ & $0,15 \%$ & $1,48 \%$ & $13,03 \%$ & $5,04 \%$ \\
\hline $\begin{array}{c}\text { Finansowanie ze źródeł } \\
\text { organizacji społecznych }\end{array}$ & $0,55 \%$ & $2,41 \%$ & $1,10 \%$ & $0,00 \%$ & $1,05 \%$ \\
\hline $\begin{array}{c}\text { Pracownicze formy } \\
\text { zabezpieczenia } \\
\text { zdrowotnego }\end{array}$ & $0,29 \%$ & $0,28 \%$ & $0,43 \%$ & $0,63 \%$ & $0,67 \%$ \\
\hline $\begin{array}{c}\text { Bezpośrednie płatności } \\
\text { pacjentów na rzecz } \\
\text { świadczeniodawców }\end{array}$ & $47,67 \%$ & $13,71 \%$ & $12,69 \%$ & $9,76 \%$ & $23,25 \%$ \\
\hline RAZEM & $100,00 \%$ & $100,00 \%$ & $100,00 \%$ & $100,00 \%$ & $100,00 \%$ \\
\hline
\end{tabular}

Źródło: Opracowanie własne na podstawie danych Organizacji Współpracy Gospodarczej i Rozwoju (https://stats.oecd.org/)

Jak wynika z Tabeli 2 , różnice pomiędzy źródłami finansowania wydatków zdrowotnych w poszczególnych państwach są wyraźne. Bezpośrednie płatności z budżetu są najniższe w obydwu krajach zachodnioeuropejskich - od 5,1\% we Francji do $6,7 \%$ w Niemczech. Natomiast w krajach Europy Wschodniej osiągają poziom od 9,2\% w Polsce i Bułgarii do 12,2\% w Czechach. Bezpośrednie finansowanie opieki zdrowotnej przez gospodarstwa domowe jest wyższe w państwach naszej części kontynentu. W Bułgarii osiąga ono bardzo wysoki poziom - 47,7\% całości wydatków. W Polsce udział ten jest ponad dwukrotnie niższy i wynosi $23,2 \%$. W Czechach osiąga poziom $13,7 \%$ i jest zbliżony do poziomu udziału tego źródła finansowania w Niemczech i Francji (chociaż w dalszym ciągu jest od nich wyższy). Głównym źródłem finansowania są jednak w większości krajów (poza Bułgarią) obowiązkowe ubezpieczenia zdrowotne. I o ile w Bułgarii źródło to przekazuje do systemu mniej środków niż płatności bezpośrednie pacjentów, to w Polsce dostarcza środków do sfinansowania ponad $60 \%$ kosztów generowanych w ochronie zdrowia, a w trzech pozostałych państwach przekracza $70 \%$.

Gromadzone w państwach europejskich dane pozwalają na identyfikację źródeł, $\mathrm{z}$ których finansowane są poszczególne funkcje systemu ochrony zdrowia.

\section{Finansowanie wydatków zdrowotnych w Czechach}

W Czechach dominującym źródłem dofinansowania ochrony zdrowia są obowiązkowe ubezpieczenia zdrowotne, co przedstawiono w Tabeli 3. 
Tabela 3. Procentowy udział poszczególnych źródel w finansowaniu glównych funkcji systemu ochrony zdrowia w Czechach w 2016 roku

\begin{tabular}{|c|c|c|c|c|c|c|c|}
\hline Wyszczególnienie & 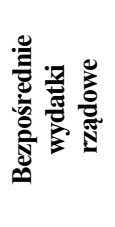 & 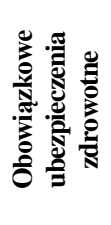 & 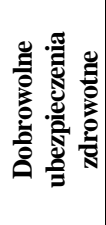 & 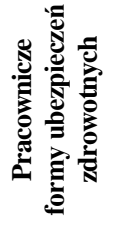 & 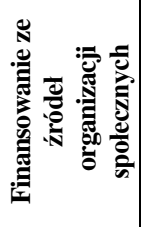 & 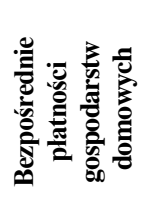 & 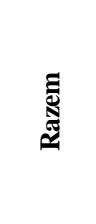 \\
\hline Szpitale & $2,3 \%$ & $95,2 \%$ & $0,0 \%$ & $0,0 \%$ & $0,0 \%$ & $2,5 \%$ & $100,0 \%$ \\
\hline $\begin{array}{c}\text { Świadczeniodawcy } \\
\text { opieki ambulatoryjnej }\end{array}$ & $0,5 \%$ & $76,5 \%$ & $0,0 \%$ & $0,0 \%$ & $0,0 \%$ & $22,9 \%$ & $100,0 \%$ \\
\hline $\begin{array}{c}\text { Ośrodki opieki } \\
\text { długoterminowej }\end{array}$ & $91,1 \%$ & $8,6 \%$ & $0,0 \%$ & $0,0 \%$ & $0,0 \%$ & $0,3 \%$ & $100,0 \%$ \\
\hline $\begin{array}{c}\text { Świadczeniodawcy } \\
\text { dodatkowych usług } \\
\text { medycznych }\end{array}$ & $32,3 \%$ & $67,7 \%$ & $0,0 \%$ & $0,0 \%$ & $0,0 \%$ & $0,0 \%$ & $100,0 \%$ \\
\hline $\begin{array}{c}\text { Świadczeniodawcy } \\
\text { profilaktyki } \\
\text { zdrowotnej }\end{array}$ & $0,0 \%$ & $25,7 \%$ & $0,0 \%$ & $74,3 \%$ & $0,0 \%$ & $0,0 \%$ & $100,0 \%$ \\
\hline $\begin{array}{c}\text { Sprzedawcy } \\
\text { i dostawcy sprzętu } \\
\text { medycznego } \\
\text { i lekarstw } \\
\end{array}$ & $0,0 \%$ & $47,4 \%$ & $0,0 \%$ & $0,0 \%$ & $0,0 \%$ & $52,6 \%$ & $100,0 \%$ \\
\hline $\begin{array}{c}\text { Administracja } \\
\text { systemu ochrony } \\
\text { zdrowia oraz usługo- } \\
\text { dawcy finansowi }\end{array}$ & $28,5 \%$ & $71,4 \%$ & $0,2 \%$ & $0,0 \%$ & $0,0 \%$ & $0,0 \%$ & $100,0 \%$ \\
\hline $\begin{array}{c}\text { Przedsiębiorstwa } \\
\text { działające w innych } \\
\text { branżach }\end{array}$ & $100,0 \%$ & $0,0 \%$ & $0,0 \%$ & $0,0 \%$ & $0,0 \%$ & $0,0 \%$ & $100,0 \%$ \\
\hline $\begin{array}{c}\text { Usługodawcy } \\
\text { z państw trzecich }\end{array}$ & $0,0 \%$ & $4,6 \%$ & $95,4 \%$ & $0,0 \%$ & $0,0 \%$ & $0,0 \%$ & $100,0 \%$ \\
\hline $\begin{array}{c}\text { Świadczeniodawcy } \\
\text { nieokreśleni }\end{array}$ & $13,0 \%$ & $21,5 \%$ & $0,0 \%$ & $0,0 \%$ & $65,5 \%$ & $0,0 \%$ & $100,0 \%$ \\
\hline
\end{tabular}

Źródło: Opracowanie własne na podstawie danych Organizacji Współpracy Gospodarczej i Rozwoju (https://stats.oecd.org/)

$\mathrm{Z}$ danych przedstawionych w Tabeli 3 wynika jednoznacznie, że istnieją pewne funkcje systemu ochrony zdrowia, w których udział finansowania z obowiązkowych ubezpieczeń obniża się. Opieka długoterminowa w niemal $2 / 3$ finansowana jest bezpośrednio z budżetu państwa, odciążając tym samym powszechny system ubezpieczeniowy. Różne pozostałe funkcje związane z ochroną zdrowia, pod którymi kryją się zazwyczaj pewne specyficzne usługi świadczone na terenie danego kraju, z rozmaitych względów nie są klasyfikowane w żadnej z pozostałych funkcji systemu. W Czechach tę specyficzną grupę kosztów ponoszą w głównej mierze organizacje społeczne niezależne od rządu. Pracownicze formy ubezpieczeń pełnią niewielką rolę w profilaktyce zdrowotnej. Stanowią one zaledwie $1 / 8$ jej kosztów. Natomiast płatności bezpośrednie gospodarstw domowych pokrywają 44\% kosztów leków i urządzeń medycznych oraz 11,4\% kosztów leczenia i rehabilitacji. 
Finansowanie podstawowych typów zakładów zapewniających usługi medyczne szpitali, ambulatoriów, zakładów usług pomocniczych - w głównej części pokrywane jest ze środków powszechnego ubezpieczenia zdrowotnego. Ambulatoria i praktyki lekarskie w niemal 23\% finansowane są bezpośrednio przez pacjentów, natomiast zakłady usług okołomedycznych w 32\% finansowane są ze środków budżetowych. Finansowanie pozostałych rodzajów podmiotów funkcjonujących w sektorze usług zdrowotnych jest odmienne. Koszt funkcjonowania ośrodków opieki długoterminowej w 91,1\% pokrywają środki budżetowe, a jedynie w 8,6\% pochodzą z obowiązkowego ubezpieczenia medycznego. Instytucje profilaktyki zdrowotnej finansują w 74\% różne formy pracowniczych ubezpieczeń zdrowotnych, a w pozostałej części - ubezpieczenia powszechne. Sprzedawcy lekarstw i sprzętu medycznego opłacani są w 52,6\% ze środków prywatnych, resztę uzyskują z ubezpieczeń obowiązkowych. Usługodawcy z państw trzecich finansowani są w $95 \%$ z ubezpieczeń dobrowolnych. Natomiast świadczeniodawcy nieokreśleni w 65,5\% otrzymują środki pochodzące z organizacji społecznych, w $21,5 \%$ z powszechnego ubezpieczenia zdrowotnego, a w 13\% z budżetu państwa.

\section{Finansowanie usług zdrowotnych w Bulgarii}

Zróżnicowanie $\mathrm{w}$ finansowaniu poszczególnych funkcji systemu jest w Bułgarii większe niż w Czechach. Zwraca uwagę dominująca rola płatności bezpośrednich od pacjentów dla świadczeniodawców w zakresie opieki długoterminowej oraz przy sprzedaży produktów leczniczych.

Bezpośrednie finansowanie budżetowe pokrywa ponad 50\% wydatków w przypadku: zarządzania systemem ochrony zdrowia, finansowania usług dodatkowych w ochronie zdrowia oraz w prowadzeniu działań profilaktycznych. Natomiast - podobnie jak w Czechach - różne nie sprecyzowane pozostałe funkcje finansowane są przez organizacje społeczne, a także około $10 \%$ kosztów tego typu pokrywane jest $\mathrm{z}$ dobrowolnych ubezpieczeń zdrowotnych. Finansowanie z ubezpieczeń obowiązkowych dotyczy przede wszystkim lecznictwa i rehabilitacji. Jednakże ich udział w finansowaniu pozostałych funkcji ochrony zdrowia jest również wysoki, a w przypadku profilaktyki zdrowotnej i usług dodatkowych sięga niemal 1/4 poziomu wydatków.

Tabela 4. Procentowy udział poszczególnych źródeł w finansowaniu glównych funkcji systemu ochrony zdrowia w Bułgarii w 2016 roku

\begin{tabular}{|c|c|c|c|c|c|c|c|}
\hline Wyszczególnienie & 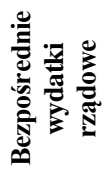 & 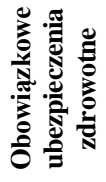 & 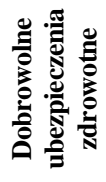 & 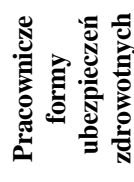 & 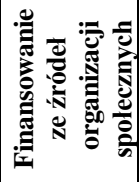 & 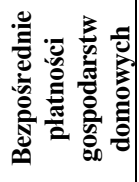 & 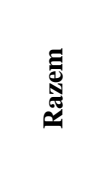 \\
\hline Szpitale & $14,2 \%$ & $73,2 \%$ & $0,1 \%$ & $0,0 \%$ & $0,0 \%$ & $12,5 \%$ & $100,0 \%$ \\
\hline $\begin{array}{c}\text { Świadczeniodawcy } \\
\text { opieki ambulatoryjnej }\end{array}$ & $0,0 \%$ & $50,8 \%$ & $1,7 \%$ & $0,0 \%$ & $0,0 \%$ & $47,5 \%$ & $100,0 \%$ \\
\hline $\begin{array}{c}\text { Ośrodki opieki } \\
\text { długoterminowej }\end{array}$ & $78,7 \%$ & $0,1 \%$ & $0,0 \%$ & $0,0 \%$ & $0,0 \%$ & $21,2 \%$ & $100,0 \%$ \\
\hline
\end{tabular}




\begin{tabular}{|c|c|c|c|c|c|c|c|}
\hline Wyszczególnienie & 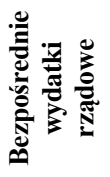 & 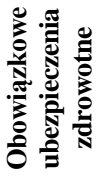 & 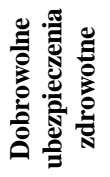 & 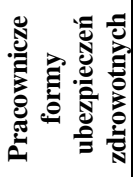 & 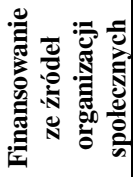 & 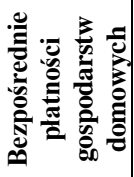 & 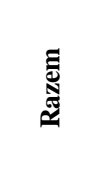 \\
\hline $\begin{array}{c}\text { Świadczeniodawcy } \\
\text { dodatkowych usług } \\
\text { medycznych }\end{array}$ & $61,0 \%$ & $12,1 \%$ & $0,0 \%$ & $0,0 \%$ & $0,0 \%$ & $27,0 \%$ & $100,0 \%$ \\
\hline $\begin{array}{l}\text { Świadczeniodawcy } \\
\text { profilaktyki zdrowotnej }\end{array}$ & $100,0 \%$ & $0,0 \%$ & $0,0 \%$ & $0,0 \%$ & $0,0 \%$ & $0,0 \%$ & $100,0 \%$ \\
\hline $\begin{array}{c}\text { Sprzedawcy i dostawcy } \\
\text { sprzętu medycznego } \\
\text { i lekarstw }\end{array}$ & $0,0 \%$ & $18,2 \%$ & $0,0 \%$ & $0,0 \%$ & $0,0 \%$ & $81,8 \%$ & $100,0 \%$ \\
\hline $\begin{array}{l}\text { Administracja systemu } \\
\text { ochrony zdrowia oraz } \\
\text { usługodawcy finansowi }\end{array}$ & $58,7 \%$ & $41,3 \%$ & $0,0 \%$ & $0,0 \%$ & $0,0 \%$ & $0,0 \%$ & $100,0 \%$ \\
\hline $\begin{array}{c}\text { Przedsiębiorstwa } \\
\text { działające w innych } \\
\text { branżach }\end{array}$ & $32,6 \%$ & $0,0 \%$ & $2,8 \%$ & $16,9 \%$ & $31,9 \%$ & $15,8 \%$ & $100,0 \%$ \\
\hline $\begin{array}{l}\text { Usługodawcy } \\
\text { z państw trzecich }\end{array}$ & $0,0 \%$ & $100,0 \%$ & $0,0 \%$ & $0,0 \%$ & $0,0 \%$ & $0,0 \%$ & $100,0 \%$ \\
\hline $\begin{array}{l}\text { Świadczeniodawcy } \\
\text { nieokreśleni }\end{array}$ & $0,0 \%$ & $0,0 \%$ & $100,0 \%$ & $0,0 \%$ & $0,0 \%$ & $0,0 \%$ & $100,0 \%$ \\
\hline
\end{tabular}

Źródło: Opracowanie własne na podstawie danych Organizacji Współpracy Gospodarczej i Rozwoju (https://stats.oecd.org/)

Bułgaria charakteryzuje się bardzo zróżnicowanym finansowaniem opieki zdrowotnej. Szpitale finansowane są w 73,2\% ze środków ubezpieczenia obowiązkowego. Pozostałe środki zapewniają budżet państwa i opłaty wnoszone bezpośrednio przez pacjentów. Z kolei ambulatoryjne zakłady opieki zdrowotnej otrzymują na ogół w równym stopniu pieniądze pochodzące bezpośrednio od leczonych pacjentów oraz $\mathrm{z}$ puli ubezpieczenia obowiązkowego. Ośrodki opieki długoterminowej w 78,7\% utrzymywane są przez budżet państwa, a w $21,2 \%$ finansowane są ze środków prywatnych pacjentów i ich rodzin. Usługodawcy dodatkowych świadczeń okołomedycznych otrzymują większość środków finansowych od państwa (ponad 60\%), podczas gdy bezpośrednie płatności gospodarstw domowych wynoszą w tym przypadku $27 \%$, a ubezpieczenia powszechne jako źródło finansowania stanowią tylko $12 \%$. W Bułgarii utrzymanie instytucji odpowiedzialnych za profilaktykę zdrowotną spoczywa w całości na budżecie państwa. Działania profilaktyczne realizowane są również poza tymi instytucjami, ponieważ profilaktyka zdrowotna, jako funkcja systemu ochrony zdrowia, finansowana jest także w $25 \%$ ze źródeł ubezpieczenia obowiązkowego i w $12 \%$ w ramach różnych pracowniczych form ubezpieczeniowych.

Sprzedawcy medykamentów i innego sprzętu medycznego otrzymują 81,8\% wpływów ze źródeł gospodarstw domowych. W Bułgarii zakupy leków i urządzeń medycznych najsilniej obarczają pacjentów. Usługodawcy z innych państw opłacani są ze środków zgromadzonych w systemie powszechnego ubezpieczenia zdrowotnego. Natomiast świadczeniodawcy nieokreśleni realizują zadania opłacane w 100\% przez organizacje społeczne. Przedsiębiorcy działający w innych branżach, jednak 
realizujący również zadania z ochrony zdrowia, otrzymują zapłatę za swoją działalność ze wszystkich źródeł. Między innymi podmioty te odpowiadają za działania profilaktyczne opłacane z pracowniczych form ubezpieczenia zdrowotnego. Administracja systemu ochrony zdrowia pokrywa swoje wydatki w 41,3\% z systemu ubezpieczenia obowiązkowego, a w 58,7\% ze środków przekazywanych przez państwo, co odpowiada rozkładowi źródeł finansowania funkcji zarządzania systemem ochrony zdrowia przedstawionemu w Tabeli 4.

Zwraca uwagę znaczna różnica między poziomem finansowania opieki długookresowej a finansowaniem ośrodków opieki długoterminowej. W pierwszym przypadku koszty opieki w $15,6 \%$ pokrywa państwo, a w $84,4 \%$ pacjenci, w drugim przypadku odsetek ten wynosi odpowiednio 78,7\% i 21,2\%. Porównując wielkość środków przeznaczonych na opiekę długoterminową, można stwierdzić, że finansowanie ośrodków opieki długoterminowej wyniosło w Bułgarii w 2016 roku ponad $10 \mathrm{mln}$ euro, jednak na funkcję systemu polegającą na tej opiece wydano jedynie $3,34 \mathrm{mln}$ euro. Oznacza to, że ponad 2/3 środków finansowych przekazywanych tym ośrodkom wykorzystywane jest na inne rodzaje świadczeń dla pacjentów (np. na lecznictwo ambulatoryjne).

\section{Finansowanie wydatków zdrowotnych we Francji}

Francja finansuje wszystkie funkcje ochrony zdrowia (poza profilaktyką zdrowotną) za pomocą obowiązkowych ubezpieczeń zdrowotnych. Udział obowiązkowych ubezpieczeń w finansowaniu leczenia i rehabilitacji oraz dodatkowych usług w ochronie zdrowia stanowi niemal 90\%. Płatności bezpośrednie gospodarstw domowych koncentrują się na opiece długoterminowej oraz zakupie leków i urządzeń medycznych. W pierwszym przypadku dochodząc do $22,5 \%$, a w drugim do $16,8 \%$ kosztów całkowitych realizacji tych funkcji. Dobrowolne ubezpieczenia wykorzystywane są w niewielkim (kilkuprocentowym) stopniu w lecznictwie, dodatkowych usługach zdrowotnych, zakupie produktów medycznych oraz pokrywają aż $28 \%$ kosztów zarządzania systemem ochrony zdrowia.

Znacznie wyższy udział środków pochodzących z ubezpieczeń dobrowolnych w finansowaniu zarządzania i administracji w stosunku do udziału w finansowaniu innych funkcji systemu opieki zdrowotnej wynika z potwierdzonego w literaturze wyższego kosztu utrzymania rozbudowanej biurokracji w stosunku do systemu powszechnego. Koszt ten powstaje z konieczności oceny ryzyka, ustalania wartości składek, projektowania pakietów ubezpieczeniowych, utrzymywania osobnych struktur opiniowania wniosków i wypłaty świadczeń, a także konieczności ponoszenia wydatków marketingowych oraz kosztów dystrybucji ubezpieczeń (Jurkiewicz, Tinardon 2010, s. 95-105). Budżet państwa dopłaca do opieki długoterminowej prawie 20\% jej kosztów. Wraz z pracowniczymi formami ubezpieczeń zdrowotnych odpowiada za ponad $80 \%$ kosztów profilaktyki zdrowotnej. Organizacje społeczne nie mają istotnego znaczenia w finansowaniu głównych funkcji systemu ochrony zdrowia we Francji.

We Francji największy wkład w finansowanie usług we wszystkich typach jednostek (poza instytucjami zaangażowanymi w działania profilaktyczne) mają obowiązkowe ubezpieczenia zdrowotne. Ich udział w finansowaniu poszczególnych 
rodzajów placówek waha się od 56\% w ośrodkach opieki długoterminowej do 93,6\% w przypadku szpitali. Różnica ta wynika między innymi z charakteru funkcjonowania tych ostatnich. Państwa europejskie traktują opiekę długoterminową jako świadczenia socjalne dla osób, które zwykle nie rokują powrotu do pełnej sprawności fizycznej, czy to ze względu na rodzaj choroby, czy ze względu na osiągnięcie wieku emerytalnego. Stąd konieczne środki finansowe uzupełniane są z innych źródeł.

Tabela 5. Procentowy udzial poszczególnych źródel w finansowaniu głównych funkcji systemu ochrony zdrowia we Francji w 2016 roku

\begin{tabular}{|c|c|c|c|c|c|c|c|}
\hline Wyszczególnienie & 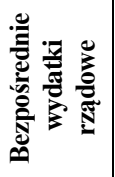 & 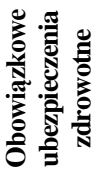 & 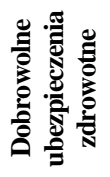 & 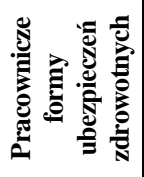 & 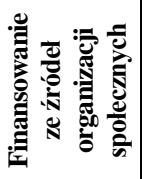 & 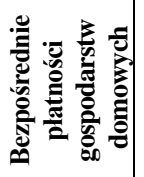 & 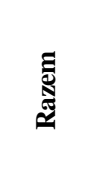 \\
\hline Szpitale & $1,1 \%$ & $93,6 \%$ & $3,1 \%$ & $0,0 \%$ & $0,0 \%$ & $2,2 \%$ & $100,0 \%$ \\
\hline $\begin{array}{c}\text { Świadczeniodawcy opieki } \\
\text { ambulatoryjnej }\end{array}$ & $8,8 \%$ & $72,4 \%$ & $8,2 \%$ & $0,0 \%$ & $0,0 \%$ & $10,6 \%$ & $100,0 \%$ \\
\hline Ośrodki opieki długoterminowej & $14,5 \%$ & $56,0 \%$ & $0,0 \%$ & $0,0 \%$ & $0,0 \%$ & $29,5 \%$ & $100,0 \%$ \\
\hline $\begin{array}{l}\text { Świadczeniodawcy dodatkowych } \\
\text { usług medycznych }\end{array}$ & $1,7 \%$ & $86,2 \%$ & $9,0 \%$ & $0,0 \%$ & $0,0 \%$ & $3,1 \%$ & $100,0 \%$ \\
\hline $\begin{array}{c}\text { Świadczeniodawcy profilaktyki } \\
\text { zdrowotnej }\end{array}$ & $27,5 \%$ & $19,1 \%$ & $0,0 \%$ & $53,3 \%$ & $0,0 \%$ & $0,0 \%$ & $100,0 \%$ \\
\hline $\begin{array}{c}\text { Sprzedawcy i dostawcy sprzętu } \\
\text { medycznego i lekarstw }\end{array}$ & $1,4 \%$ & $70,3 \%$ & $10,5 \%$ & $0,0 \%$ & $0,0 \%$ & $17,9 \%$ & $100,0 \%$ \\
\hline $\begin{array}{c}\text { Administracja systemu ochrony } \\
\text { zdrowia oraz usługodawcy } \\
\text { finansowi }\end{array}$ & $5,2 \%$ & $66,7 \%$ & $28,1 \%$ & $0,0 \%$ & $0,0 \%$ & $0,0 \%$ & $100,0 \%$ \\
\hline $\begin{array}{l}\text { Przedsiębiorstwa działające } \\
\text { w innych branżach }\end{array}$ & $23,3 \%$ & $73,9 \%$ & $1,4 \%$ & $0,0 \%$ & $0,0 \%$ & $1,4 \%$ & $100,0 \%$ \\
\hline
\end{tabular}

Źródło: Opracowanie własne na podstawie danych Organizacji Współpracy Gospodarczej i Rozwoju (https://stats.oecd.org/)

Z kolei podmioty zaangażowane w realizację profilaktyki zdrowotnej w największym zakresie finansowane są z pracowniczych form ubezpieczeniowych $(53,3 \%)$, a w dalszej kolejności z budżetu państwa (27,5\%). Profilaktyka zdrowotna wiąże się bowiem z zapobieganiem utracie czasowej lub stałej pracowników w wyniku przechodzonych chorób lub zaistniałych urazów. Leczenie wiąże się każdorazowo z utratą roboczogodzin, niezależnie od jego wyniku.

Gospodarstwa domowe dokonują bezpośredniego zakupu usług świadczeniodawców opieki ambulatoryjnej (10,6\% ogółu wydatków w tym sektorze), opieki długoterminowej $(29,5 \%)$ oraz finansują w 17,9\% zakup leków i sprzętu medycznego. Dobrowolne ubezpieczenia zdrowotne współuczestniczą od 8,2\% do 10,5\% w finansowaniu ośrodków ambulatoryjnych, usług dodatkowych okołomedycznych oraz w zakupach sprzętu i medykamentów. Natomiast ich udział w opłacaniu usług instytucji finansowych - najczęściej ubezpieczeniowych oraz administracji systemu ochrony zdrowia osiąga aż 28,1\% całości kosztów funkcjonowania tej grupy podmiotów. Państwo francuskie bezpośrednio z budżetu państwa pokrywa $23,5 \%$ usług świadczonych przez przedsiębiorstwa działające $w$ innych sektorach gospodarki za ich usługi klasyfikowane 
w sektorze zdrowia oraz 27,5\% wydatków na rzecz podmiotów zajmujących się profilaktyką zdrowia. Udział państwa w finansowaniu szpitali, świadczeniodawców usług dodatkowych oraz sprzedawców leków i urządzeń medycznych nie przekracza $2 \%$. Z wcześniejszej analizy wynikało, że budżet państwa pokrywa $48 \%$ wydatków ponoszonych we Francji na działania profilaktyczne. Stąd można wnosić, że wydatki ponoszone na profilaktykę i usługi zakupywane $\mathrm{w}$ jednostkach realizujących zadania profilaktyki zdrowotnej nie są tożsame, o czym wspomniano wcześniej. Z prezentowanych powyżej danych wynika, że około $30-40 \%$ działań profilaktyki w ochronie zdrowia realizowanych jest we Francji poza podmiotami, których głównym zadaniem jest realizacja tych zadań. Można przypuszczać, że zakup usług profilaktycznych realizowanych w szpitalach, ośrodkach lecznictwa ambulatoryjnego czy też przez przedsiębiorstwa spoza sektora ochrony zdrowia dokonywany jest ze środków budżetowych.

\section{Finansowanie ochrony zdrowia w Niemczech}

Finansowanie ochrony zdrowia w Niemczech nie odstaje od systemu francuskiego. Każda $\mathrm{z}$ raportowanych głównych funkcji systemu finansowana jest głównie $\mathrm{z}$ obowiązkowych składek ubezpieczenia zdrowotnego, przy czym w żadnej funkcji poziom tego finansowania nie spada poniżej $60 \%$. Inne źródła finansowania mają znaczenie mniejsze niż we Francji. Bezpośrednie płatności prywatne na rzecz świadczeniodawców występują głównie przy opiece długoterminowej oraz zakupie medykamentów.

Tabela 6. Procentowy udział poszczególnych źródeł w finansowaniu głównych funkcji systemu ochrony zdrowia w Niemczech w 2016 roku

\begin{tabular}{|c|c|c|c|c|c|c|c|}
\hline Wyszczególnienie & 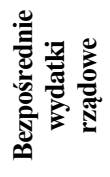 & 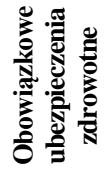 & 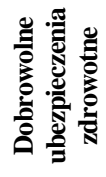 & 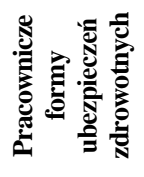 & 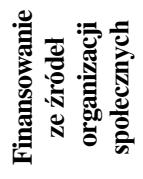 & 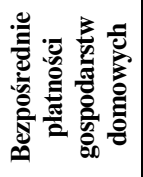 & ฮี \\
\hline Szpitale & $6,3 \%$ & $89,7 \%$ & $1,7 \%$ & $0,2 \%$ & $0,6 \%$ & $1,4 \%$ & $100,0 \%$ \\
\hline $\begin{array}{c}\text { Świadczeniodawcy opieki } \\
\text { ambulatoryjnej }\end{array}$ & $7,1 \%$ & $76,2 \%$ & $1,6 \%$ & $0,2 \%$ & $2,1 \%$ & $12,8 \%$ & $100,0 \%$ \\
\hline $\begin{array}{c}\text { Ośrodki opieki } \\
\text { długoterminowej }\end{array}$ & $13,1 \%$ & $46,0 \%$ & $0,0 \%$ & $0,1 \%$ & $3,2 \%$ & $37,6 \%$ & $100,0 \%$ \\
\hline $\begin{array}{c}\text { Świadczeniodawcy dodatko- } \\
\text { wych usług medycznych }\end{array}$ & $3,4 \%$ & $93,4 \%$ & $0,3 \%$ & $0,1 \%$ & $1,7 \%$ & $1,1 \%$ & $100,0 \%$ \\
\hline $\begin{array}{c}\text { Świadczeniodawcy profilak- } \\
\text { tyki zdrowotnej }\end{array}$ & $100,0 \%$ & $0,0 \%$ & $0,0 \%$ & $0,0 \%$ & $0,0 \%$ & $0,0 \%$ & $100,0 \%$ \\
\hline $\begin{array}{l}\text { Sprzedawcy i dostawcy } \\
\text { sprzętu medycznego } \\
\text { i lekarstw }\end{array}$ & $4,3 \%$ & $71,5 \%$ & $0,4 \%$ & $0,2 \%$ & $0,0 \%$ & $23,6 \%$ & $100,0 \%$ \\
\hline $\begin{array}{l}\text { Administracja systemu } \\
\text { ochrony zdrowia oraz } \\
\text { usługodawcy finansowi }\end{array}$ & $1,2 \%$ & $93,3 \%$ & $5,5 \%$ & $0,0 \%$ & $0,0 \%$ & $0,0 \%$ & $100,0 \%$ \\
\hline $\begin{array}{l}\text { Przedsiębiorstwa działające } \\
\text { w innych branżach }\end{array}$ & $3,6 \%$ & $88,3 \%$ & $0,0 \%$ & $7,9 \%$ & $0,0 \%$ & $0,2 \%$ & $100,0 \%$ \\
\hline $\begin{array}{l}\text { Usługodawcy z państw } \\
\text { trzecich }\end{array}$ & $0,0 \%$ & $91,6 \%$ & $8,4 \%$ & $0,0 \%$ & $0,0 \%$ & $0,0 \%$ & $100,0 \%$ \\
\hline
\end{tabular}

Źródło: Opracowanie własne na podstawie danych Organizacji Współpracy Gospodarczej i Rozwoju (https://stats.oecd.org/) 
Podobnie jak w innych analizowanych państwach, również w Niemczech pracownicze formy ubezpieczenia wiodącą rolę odgrywają w profilaktyce, gdzie pokrywają 8,6\% wydatków. Finansowanie budżetowe jest rozłożone równomiernie i pokrywa od 5\% do $10 \%$ kosztów poszczególnych funkcji, z wyjątkiem profilaktyki, w której jego udział wzrasta do 20,5\%, oraz kosztów zarządzania, w których jego udział spada do 1,3\%. Podobnie jak we Francji, spośród wszystkich funkcji najwyższy udział w zarządzaniu systemem mają dobrowolne ubezpieczenia zdrowotne. Organizacje społeczne ze swoich źródeł pokrywają nieco ponad 5\% kosztów opieki długoterminowej.

W Niemczech finansowanie poszczególnych rodzajów usługodawców nie odbiega zasadniczo od modelu francuskiego. Natomiast odmienne jest 100-procentowe finansowanie instytucji zajmujących się profilaktyką zdrowotną bezpośrednio przez państwo. W finansowaniu szpitali, świadczeniodawców usług dodatkowych w ochronie zdrowia oraz w zakupach od dostawców leków i innych produktów medycznych udział państwa jest również wyższy niż we Francji i przekracza odpowiednio $6,3 \%, 3,4 \%$ i $4 \%$ wydatków na te rodzaje świadczeniodawców. Natomiast finansowanie instytucji zarządzających i finansujących usługi $\mathrm{w}$ ochronie zdrowia w Niemczech ze źródeł rządowych jest niższe niż we Francji i osiąga jedynie 1,2\% całości wydatków na ich usługi. Podobnie jak we Francji, gospodarstwa domowe najwięcej środków przeznaczają na ośrodki opieki długoterminowej, jak również przekazują sprzedawcom oraz dostawcom leków i sprzętu medycznego.

W Niemczech raportowana jest także nieistniejąca w Narodowym Rachunku Zdrowia we Francji kategoria usługodawców zlokalizowanych poza granicami kraju. W tej kategorii najistotniejszym donatorem środków pieniężnych są obowiązkowe ubezpieczenia zdrowotne, jednak istotny udział w finansowaniu wydatków mają również środki pochodzące z dobrowolnych ubezpieczeń zdrowotnych $(8,4 \%)$. Typowe dla funkcjonowania ubezpieczeń dobrowolnych jest także finansowanie utrzymywania administracji oraz instytucji finansowych. Udział ten jest dość wysoki $(5,5 \%)$ i przekracza poziom finansowania $z$ tego źródła pozostałych świadczeniodawców usług zdrowotnych. Największy udział środki te mają w finansowaniu szpitali ( $1,7 \%$ całości wydatków na ten cel). Należy podkreślić, że finansowanie instytucji zaangażowanych $\mathrm{w}$ profilaktykę zdrowotną pochodzi w całości ze środków budżetowych, podczas gdy finansowanie działań profilaktycznych w ponad $70 \%$ pokrywają środki pochodzące z obowiązkowych ubezpieczeń społecznych. Działania profilaktyczne realizowane są w Niemczech nie tylko przez instytucje powołane do ich przeprowadzania. Głównym wykonawcą zadań profilaktycznych są także instytucje finansowane w większości ze środków ubezpieczeń zdrowotnych. Są to szpitale oraz lecznictwo ambulatoryjne.

\section{Finansowanie wydatków zdrowotnych w Polsce}

Struktura źródeł finansowania ochrony zdrowia w Polsce odbiega od modelu zachodnioeuropejskiego. Zwraca uwagę znacznie niższy niż we Francji i Niemczech poziom finansowania poszczególnych funkcji z obowiązkowych składek ubezpieczenia zdrowotnego. Jedynie lecznictwo i rehabilitacja finansowane są $\mathrm{z}$ obowiązkowych 
ubezpieczeń na poziomie powyżej 50\% całkowitych kosztów. Wiele z funkcji finansowanych jest bezpośrednio z budżetu państwa na poziomie ponad $50 \%$ całości kosztów. Są to: opieka długoterminowa, profilaktyka zdrowotna, zarządzanie systemem ochrony zdrowia. Natomiast udział budżetu w finansowaniu lecznictwa, zakupu leków oraz urządzeń jest minimalny i wynosi od $1,4 \%$ do $2,7 \%$. Największy udział w kosztach leków i zakupach urządzeń medycznych mają płatności bezpośrednie pacjentów. Udział ten wynosi prawie $65 \%$. Bezpośrednie wydatki gospodarstw domowych mają również istotny udział $(10 \%)$ w pokrywaniu kosztów leczenia oraz usług dodatkowych w ochronie zdrowia. Na nieco niższym poziomie w tych kategoriach plasują się dobrowolne ubezpieczenia zdrowotne, których udział w kosztach zarządzania ochroną zdrowia jest bardzo niski. Podobnie jak w pozostałych państwach, wkład pracowniczych form ubezpieczenia w profilaktykę zdrowotną jest istotny i wynosi prawie $30 \%$. W Polsce, podobnie jak w Bułgarii i Czechach, raportuje się osobno pozostałe funkcje w ochronie zdrowia. Jest to kategoria zbiorcza obejmująca nieklasyfikowane gdzie indziej usługi medyczne i okołomedyczne, których włączenie do głównych funkcji systemu ochrony zdrowia $\mathrm{z}$ różnych względów jest utrudnione. Także w Polsce istotny jest udział finansowania ze źródeł organizacji społecznych tej zbiorczej funkcji.

Tabela 7. Procentowy udział poszczególnych źródeł w finansowaniu głównych funkcji systemu ochrony zdrowia w Polsce w 2016 roku

\begin{tabular}{|c|c|c|c|c|c|c|c|}
\hline Wyszczególnienie & 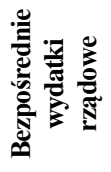 & 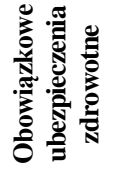 & 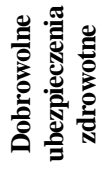 & 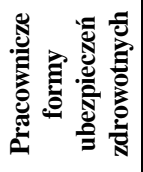 & 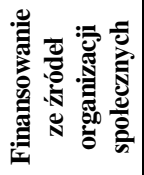 & 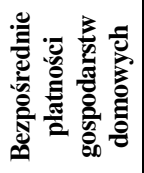 & हี \\
\hline Szpitale & $3,8 \%$ & $91,1 \%$ & $2,7 \%$ & $0,0 \%$ & $0,6 \%$ & $1,8 \%$ & $100,0 \%$ \\
\hline $\begin{array}{c}\text { Świadczeniodawcy opieki } \\
\text { ambulatoryjnej }\end{array}$ & $1,8 \%$ & $56,1 \%$ & $13,9 \%$ & $3,3 \%$ & $0,3 \%$ & $24,6 \%$ & $100,0 \%$ \\
\hline $\begin{array}{c}\text { Ośrodki opieki } \\
\text { długoterminowej }\end{array}$ & $2,3 \%$ & $83,1 \%$ & $0,0 \%$ & $0,0 \%$ & $13,6 \%$ & $1,0 \%$ & $100,0 \%$ \\
\hline $\begin{array}{l}\text { Świadczeniodawcy dodatko- } \\
\text { wych usług medycznych }\end{array}$ & $35,0 \%$ & $41,0 \%$ & $10,0 \%$ & $0,0 \%$ & $3,6 \%$ & $10,4 \%$ & $100,0 \%$ \\
\hline $\begin{array}{c}\text { Świadczeniodawcy } \\
\text { profilaktyki zdrowotnej }\end{array}$ & $6,9 \%$ & $0,0 \%$ & $0,0 \%$ & $0,0 \%$ & $93,1 \%$ & $0,0 \%$ & $100,0 \%$ \\
\hline $\begin{array}{c}\text { Sprzedawcy i dostawcy sprzętu } \\
\text { medycznego i lekarstw }\end{array}$ & $0,6 \%$ & $33,5 \%$ & $0,0 \%$ & $0,0 \%$ & $0,5 \%$ & $65,4 \%$ & $100,0 \%$ \\
\hline $\begin{array}{l}\text { Administracja systemu } \\
\text { ochrony zdrowia oraz } \\
\text { usługodawcy finansowi }\end{array}$ & $80,1 \%$ & $19,9 \%$ & $0,0 \%$ & $0,0 \%$ & $0,0 \%$ & $0,0 \%$ & $100,0 \%$ \\
\hline $\begin{array}{c}\text { Przedsiębiorstwa działające } \\
\text { w innych branżach }\end{array}$ & $83,9 \%$ & $16,1 \%$ & $0,0 \%$ & $0,0 \%$ & $0,0 \%$ & $0,0 \%$ & $100,0 \%$ \\
\hline $\begin{array}{l}\text { Usługodawcy z państw } \\
\text { trzecich }\end{array}$ & $0,1 \%$ & $74,0 \%$ & $25,9 \%$ & $0,0 \%$ & $0,0 \%$ & $0,0 \%$ & $100,0 \%$ \\
\hline
\end{tabular}

Źródło: Opracowanie własne na podstawie danych Organizacji Współpracy Gospodarczej i Rozwoju (https://stats.oecd.org/)

W modelu funkcjonowania ochrony zdrowia w Polsce koszty na rzecz podstawowych świadczeniodawców usług zdrowotnych finansowane są z systemu powszechnego ubezpieczenia zdrowotnego, które pokrywa 91,1\% wydatków na szpitale, 
83,1\% wydatków na ośrodki opieki długoterminowej, 56,1\% wydatków na ambulatoria. Udział wydatków z budżetu państwa na te trzy typy instytucji jest minimalny i nie przekracza 4\%. Należy zwrócić jednak uwagę, że udział finansowania ze źródeł prywatnych oraz dobrowolnych ubezpieczeń zdrowotnych jest znaczący w przypadku świadczeniodawców prowadzących działalność ambulatoryjną i łącznie wynosi niemal 45\%. W przypadku ośrodków opieki długoterminowej aż 13,6\% kosztów ponoszą organizacje społeczne. $Z$ tego źródła pokrywane jest również 93,1\% należności wobec instytucji odpowiedzialnych za prowadzenie profilaktyki zdrowotnej (pozostałe środki dostarcza budżet państwa). Największą różnorodnością źródeł finansowania charakteryzują się w Polsce dostarczyciele usług dodatkowych. W ich finansowaniu uczestniczy budżet państwa (35\%), system powszechnego ubezpieczenia zdrowotnego $(41 \%)$, ubezpieczyciele prywatni (10\%), gospodarstwa domowe $(10,4 \%)$ oraz organizacje społeczne $(3,6 \%)$.

Podobnie jak w większości państw europejskich, udział wydatków gospodarstw domowych w zakupach urządzeń i wyrobów medycznych jest największy i przekracza $65 \%$, pozostałe wydatki na rzecz sprzedawców i producentów ponosi budżet państwa. Państwo jest także dominującym płatnikiem za usługi przedsiębiorstw $\mathrm{z}$ innych branż udzielających się $\mathrm{w}$ ochronie zdrowia oraz ponosi większość wydatków związanych $z$ administrowaniem systemem ochrony zdrowia i usługami finansowymi na jego rzecz. W tych przypadkach pokrywa ponad $80 \%$ wydatków na rzecz tych podmiotów. Usługi podmiotów zagranicznych pokrywane są ze środków NFZ w 75\%, 25\% opłacają ubezpieczyciele działający na rynku prywatnych, nieobowiązkowych ubezpieczeń zdrowotnych.

\section{Podsumowanie}

Biorąc pod uwagę wzajemne powiązanie źródeł finansowania usług zdrowotnych oraz rodzajów świadczeniodawców ich udzielających, uzyskuje się nieco inny obraz finansowania ochrony zdrowia. Jest on w pewnym stopniu podobny do opisywanych związków pomiędzy funkcjami systemu ochrony zdrowia a źródłami ich finansowania. Wynika to między innymi z silnego związku pomiędzy rodzajami placówek i usługami w nich wykonywanymi. Jednakże, jak wykazała analiza, dają się zaobserwować również pewne różnice. Powstają one na skutek nieco odmiennego zakresu świadczeń zdrowotnych udzielanych w placówkach tego samego typu w różnych państwach, co z kolei ma związek z organizacją systemu ochrony zdrowia.

Z przedstawionych rozważań wynika, że obecnie rozwinięte państwa w znacznej większości preferują systemy opieki zdrowotnej w przeważającej mierze finansowane ze środków publicznych, a sam system opieki zdrowotnej podlega daleko idącej kontroli i zarządzaniu przez instytucje państwa. Równocześnie w państwach demokratycznych wspiera się różnorodne formy solidaryzmu społecznego w zakresie ochrony zdrowia, chociaż w jednych krajach akceptuje się bardzo szeroki zakres interwencjonizmu państwowego $\mathrm{w}$ ochronie zdrowia, a w innych znacznie węższy. Zakres odpowiedzialności państwa za ochronę zdrowia oraz jej formy są różne w poszczególnych krajach Europy. Różnice wynikają w większym stopniu z procesu historycznego niż świadomych decyzji różnicujących poszczególne modele. Można 
zauważyć, że w państwach bogatszych zakres ten jest szerszy (Niemcy i Francja) niż w krajach biedniejszych (Polska, Bułgaria). Model obowiązujący w Czechach ma charakter pośredni.

Należy podkreślić, że różnice pomiędzy modelami nie mają charakteru jakościowego, a ilościowy. Faktem jest, że finansowanie służby zdrowia we Francji w większym stopniu spoczywa na barkach państwa niż w Polsce, ale nie jest to efektem różnicy w modelu, lecz możliwości finansowych obydwu państw. We Francji zgromadzone środki pozwalają na finansowanie większej liczby procedur medycznych, co przekłada się na procentowo większy udział finansowania publicznego niż w Polsce. W Polsce liczba procedur medycznych finansowanych ze źródeł publicznych jest ograniczona. W ten sposób częściej niż we Francji procedury te są bezpośrednio finansowane przez osoby prywatne lub opłacane ze środków pozapublicznych (abonamenty, ubezpieczenia dodatkowe, środki organizacji społecznych).

Podobieństwo porównywanych systemów finansowania ochrony zdrowia w poszczególnych krajach ma daleko idące konsekwencje dla kształtowania przyszłej polityki w tym zakresie. Nie można wskazać konkretnego modelu i uznać go za wzorcowy. Faktycznie jest odmiennie. To ogólny poziom możliwości finansowych państwa decyduje o proporcjach pomiędzy poszczególnymi źródłami finansowania. Wydaje się również, że zakres nie tylko opłacanych ze środków publicznych, ale i oferowanych w ogóle usług medycznych i okołomedycznych determinowany jest przez poziom zamożności społeczeństwa.

Trwające nieustannie dyskusje o przewagach różnych form finansowania usług medycznych opierają się na modelach teoretycznych, które nie są weryfikowalne w praktyce. Przeprowadzona analiza wskazuje, że najczęściej postulowane zmiany, czyli wprowadzenie do systemu powszechnego ubezpieczenia zdrowotnego podmiotów prywatnych, nie przybliżą polskiego sektora ochrony zdrowia do efektywniejszych modeli zachodnioeuropejskich. Wręcz przeciwnie, problemem funkcjonowania powszechnego ubezpieczenia zdrowotnego w Polsce nie są bynajmniej błędy w zarząadzaniu tymi środkami, lecz nieustannie niższa niż w bogatszych krajach europejskich wielkość dostępnych środków finansowych.

Nie oznacza to jednak całkowitego odrzucenia możliwości poprawy funkcjonowania systemu ochrony zdrowia. Jego poprawa powinna jednak następować poprzez procesy optymalizacyjne, które bez zakłócania funkcjonowania sektora będą udoskonalały poszczególne jego elementy. Zmiany w systemie ochrony zdrowia dokonywane pod silną presją zazwyczaj są niedopracowane, a ich koszt dodatkowo obniża dostępną na potrzeby opłacania usług zdrowotnych pulę pieniędzy.

Należy istotnie poprawić system sprawozdawczości, na której opiera się Narodowy Rachunek Zdrowia. Obecnie stosowany model określa, kto, komu i za jaką usługę zdrowotną płaci. Założenie modelu jest sensowne. Stosowane jest dzięki takim organizacjom międzynarodowym jak Organizacja Współpracy Gospodarczej i Rozwoju czy Unia Europejska. Zgodnie z założeniami modelu raporty sporządzane przez poszczególne państwa członkowskie obydwu organizacji mają zapewnić informację pełną, wiarygodną oraz porównywalną pomiędzy poszczególnymi państwami. Niestety nie można uznać, że sprawozdawczość prowadzona przez kraje 
członkowskie zapewnia pełną informację, wiarygodną oraz porównywalną. W istocie każde z państw nieco inaczej definiuje pojedyncze kategorie, w ramach których sumują wydatki sektora usług medycznych. Szczególnie widoczne jest to między innymi $\mathrm{w}$ kategoriach słabo sprecyzowanych kosztów zarządzania systemem ochrony zdrowia. We Francji koszt ten został określony na poziomie 5,74\% całości wydatków, a w Niemczech na poziomie $4,82 \%$. W tej samej kategorii Polska raportowała $1,65 \%$, a Bułgaria $1,32 \%$. Różnice w poziomie kosztów wynikają z odmiennego zakwalifikowania wydatków w tej kategorii. W Polsce i Bułgarii zaliczane są do niej jedynie centralnie ponoszone koszty administracyjne. We Francji i Niemczech włączane są w nie koszty zarządu gromadzonych funduszy oraz koszty administracyjne ponoszone przez przynajmniej niektóre jednostki opieki zdrowotnej. Innym przykładem jest kategoria: pozostałe funkcje systemu ochrony zdrowia. Kategoria łączna, do której kwalifikują się wydatki nie włączone do żadnej wcześniejszej kategorii, głównie z powodu trudności w ich dokładnym zakwalifikowaniu. W obydwu kategoriach Francja i Niemcy wykazały $0,00 \%$ wydatków, podczas gdy kraje wschodnioeuropejskie od $0,41 \%$ w Polsce do 2,72\% w Czechach. Różnice te wynikają stąd, że zarówno we Francji, jak i w Niemczech wydatki, których nie można zakwalifikować do głównych kategorii, budzą potrzebę takiego zmodyfikowania definicji kategorii, aby bliżej nieokreślone, trudne w klasyfikacji wydatki znalazły się w dookreślonych, czasem nieco rozszerzonych pozycjach. Potrzeba taka w państwach naszej części Europy nie jest tak silnie zaznaczona, stąd pojawiające się w sprawozdaniach nieznane, nieokreślone, inne wydatki są akceptowane i raportowane, a próby ich usystematyzowania nie są podejmowane zbyt energicznie.

Kolejnym zagadnieniem wymagającym podkreślenia jest problem przepływów finansowych dokonywanych wewnątrz systemu ochrony zdrowia. Część kosztów ochrony zdrowia pokrywana jest ze środków uzyskiwanych przez instytucje ochrony zdrowia w ramach realizowanych usług zdrowotnych. Przykładem może być obrót materiałami zdrowotnymi, takimi jak leki i urządzenia. Oprócz sprzedaży tych środków gospodarstwom domowym, ich czołowym odbiorcą są zakłady opieki zdrowotnej. Zakłady te finansują swoje zakupy ze środków pozyskiwanych ze sprzedaży usług zdrowotnych przez siebie świadczonych. W efekcie tego rodzaju zakupy ujmowane są $\mathrm{w}$ sprawozdawczości dwukrotnie. Pierwszy raz w formie zapłaty producentom lub pośrednikom w handlu materiałami zdrowotnymi, drugi raz poprzez zapłatę za świadczone za ich pomocą świadczenia na rzecz świadczeniobiorców. Innym podobnym przypadkiem jest wynajem pomieszczeń jednego zakładu opieki zdrowotnej na rzecz innego.

Bardzo trudne do oszacowania i włączenia do Narodowego Rachunku Zdrowia jest określenie kosztu administracji systemu zdrowia. W Polsce działa szereg instytucji odpowiedzialnych za całokształt funkcjonowania systemu ochrony zdrowia. Należą do niego instytucje centralne: Ministerstwo Zdrowia, Narodowy Fundusz Zdrowia, przedstawiciele rządu w terenie - urzędy wojewódzkie (w szczególności ich wydziały zdrowia), ale także administracja samorządowa (wydziały zdrowia urzędów marszałkowskich, starostw powiatowych czy też urzędów gmin). Należy tu także dodać urzędy samorządu zawodowego, lekarskiego czy farmaceutycznego, które utrzymywane są z obowiązkowych składek personelu medycznego. Pełnią one 
szereg niezbędnych w systemie ochrony zdrowia zadań. Także koszt zarządu środkami gromadzonymi w ramach ubezpieczeń dobrowolnych stanowi koszt administracyjny systemu. Zysk wypracowywany i wypłacany udziałowcom tego rodzaju instytucji w istocie jest takim samym kosztem jak płace urzędników ministerialnych. Poza wymienionymi ewidentnymi kosztami administracyjnymi pozostają również koszty trudne do szacowania - koszty nadzoru i kontroli. Działalność administracyjna prowadzona przez pracowników przypisanych całkowicie do zadań związanych $\mathrm{z}$ zarządzaniem ochroną zdrowia nadzorowana jest przez pracowników wyższych szczebli, których zakres obowiązków wykracza poza sektor usług zdrowotnych. Przykładowo można tu wymienić: zarządy przedsiębiorstw finansowych, ich działy audytu i kontroli wewnętrznej, organy państwa - wojewodowie, zarządy województw itp. Praca przez nich wykonywana częściowo obejmuje swoim zakresem zagadnienia ochrony zdrowia, jednak wyliczenie kosztu tego wkładu ponoszonego przez świadczeniobiorców jest trudne. Znacznie łatwiejsze jest określenie kosztów administracyjnych funkcjonowania zakładów opieki zdrowotnej. Problematyczne w tym względzie jest zakwalifikowanie tego rodzaju wydatków. Powszechnie traktuje się koszty administracyjne jako immanentną część składową kosztów usług medycznych. Sprzedaż usług zarówno opłacanych bezpośrednio przez pacjentów, refinansowanych z NFZ czy też opłacanych w formie abonamentów włączana jest w systemach księgowych do wspólnej kategorii przychodów operacyjnych jednostek. Jednak ich dalsze wykorzystanie jest już zróżnicowane: część środków przeznaczana jest na zakup środków medycznych niezbędnych w procesie leczenia, część na opłacenie wynagrodzeń personelu medycznego, część pokrywa koszty administracyjne i inne różnego rodzaju usługi pomocnicze. W sprawozdawczości przekazywanej Głównemu Urzędowi Statystycznemu w celu przygotowania Narodowego Rachunku Zdrowia tego rodzaju wyszczególnienie końcowych kosztów nie jest przedstawiane. Faktycznie dane informują o stronie przychodowej funkcjonowania zakładów opieki zdrowotnej. O stronie ponoszonych przez nich wydatków dane mają charakter wybiórczy.

\section{Literatura}

1. Gierusz A., Jackowska B., Szreder M. (2014), Obowiąek czy dobrowolność ubezpieczenia wybrane aspekty ekonomiczne, „Zarządzanie i Finanse”, $\mathrm{nr} 1$.

2. GUS (2016), Narodowy Rachunek Zdrowia za 2016, informacja sygnalna, Główny Urząd Statystyczny, Warszawa, https://stat.gov.pl/obszary-tematyczne/zdrowie/zdrowie/narodowyrachunek-zdrowia-za-2016-rok,4,9.html (dostęp: 28.05.2019).

3. GUS (2017), Zdrowie i ochrona zdrowia w 2016 r., Główny Urząd Statystyczny, Warszawa.

4. Holly R. (2013), Ubezpieczenie w organizacji ochrony zdrowia w Polsce, Krajowy Instytut Ubezpieczeń, Warszawa.

5. https://stats.oecd.org/ (dostęp: 28.05.2019).

6. Jurkiewicz I., Tinardon C. (2010), Rynek prywatnych ubezpieczeń zdrowotnych w krajach europejskich. Przyktad rozwiazań francuskich, „Zeszyty Naukowe Ochrony Zdrowia. Zdrowie Publiczne i Zarządzanie", t. 8, nr 1. 
7. Jurkiewicz-Świętek I. (2012), Dobrowolne prywatne ubezpieczenia zdrowotne. Propozycje $i$ debata wokót ich wprowadzenia w Polsce, „Zeszyty Naukowe Ochrony Zdrowia. Zdrowie Publiczne i Zarządzanie” Instytut Zdrowia Publicznego Wydziału Nauk o Zdrowiu Uniwersytetu Jagiellońskiego, nr 10(B).

8. Lach D.E. (2016), Europeizacja opieki zdrowotnej - trzy perspektywy, „Praca i Zabezpieczenie Społeczne", nr 2.

9. Mossialos E., Thompson S. (2004), Voluntary Health Insurance in the European Union, European Observatory on Health Systems and Policies, Brussels.

10. NFZ (2012), Świadczenia opieki zdrowotnej finansowane ze środków publicznych, Narodowy Fundusz Zdrowia, Warszawa.

11. OECD, Eurostat, WHO (2011), A System of Health Accounts, OECD Publishing.

12. Piechota A. (2014), Miejsce i rola ubezpieczeń w systemie ochrony zdrowia w Polsce, „Studia Ekonomiczne", nr 198, cz. 2.

13. Sagan A., Thompson S. (2016), Voluntary Health Insurance in Europe. Role and Regulation, European Observatory on Health Systems and Policies, Brussels.

14. Skowron-Grabowska B., Jasińska K. (2019), Zarządzanie wiedza w projektach organizacji oświatowych w województwie śląskim, Wydawnictwo Politechniki Czestochowskiej, Częstochowa.

15. Stabile M., Thomson S. (2014), The Changing Role of Government in Financing Health Care: An International Perspective, „,Journal of Economic Literature”, No. 2.

16. Szumlicz T. (2005), Ubezpieczenie społeczne. Teoria dla praktyki, Oficyna Wydawnicza Branta, Warszawa-Bydgoszcz.

\title{
SOURCES OF FINANCING HEALTHCARE IN SELECTED EUROPEAN COUNTRIES - COMPARATIVE ANALYSIS
}

\begin{abstract}
Compulsory contributory health insurance is the most common source of financing healthcare expenditures in Europe. In total, it covers $40.11 \%$ of the total healthcare expenditure. Budgetary financing is the next most popular form of financing healthcare, accounting for $37.64 \%$ of the total expenditure. Other sources of financing play a subsidiary role in healthcare systems. The conducted analysis shows that the majority of developed states nowadays prefer publicly funded healthcare systems These systems are also highly controlled and managed by state institutions.
\end{abstract}

Keywords: healthcare financing, healthcare, structure of healthcare financing sources 